\section{THE PREY OF THE DUSKY LEAF-NOSED BAT HIPPOSIDEROS ATER TEMPLETON IN AUROVILLE, SOUTHERN INDIA}

\author{
Mario Eric Ramanujam ${ }^{1}$ and Boris Verzhutskii ${ }^{2}$ \\ ${ }_{1}$ Principal Investigator (Fauna) ECTDEF Project, Pitchandikulam Bio- \\ Resource Centre, Auroville, Pondicherry 605101, India \\ Address for correspondence: Research Associate, Gratitude \\ Avian Rehabilitation, Auroville, Pondicherry 605101, India \\ ${ }^{2}$ Entomologist, Palmyra Project, Aurobrindavan, Auroville, \\ Pondhicherry 605111, India \\ Email: ${ }^{1}$ tdef@auroville.org.in, ${ }^{2}$ palmyra@auroville.org.in
}

The Auroville plateau (approx. 10km. north of Pondicherry City), composed primarily of red ferralitic soil (Cuddalore series sandstone) contains some eroded ravines and gullies. One such ravine is Success Canyon $\left(11^{\circ} 98^{\prime} \mathrm{N} \& 79^{\circ} 81^{\prime} \mathrm{E}\right)$, which has a very narrow meandering $\operatorname{arm} c .25 \mathrm{~m}$. long, $c .10 \mathrm{~cm}$. wide at its narrowest point, and $c .9 \mathrm{~m}$. deep. This crevass remains cool and moist even during the hottest months of May and June (day-time temperatures can exceed $40^{\circ} \mathrm{C}$ ). The sheltered end of this crevass is the habitual day - time roost of a colony of 10-15 Hipposideros ater.

On 26 August 2003, a random sample of the droppings of H.ater was collected and analysed using a binocular microscope and established literature on insects (Borror, 1992; Mani, 1990) for all arthropod remains. The percentage of prey items consumed was divided into four categories as per Verzhutskii \& Ramanujam (2002): Basic food (>20\%), Constant food (5-20\%), Supplementary food $(1-5 \%)$ and Chance food $(<1 \%)$.

The prey of the Dusky Leaf-nosed Bat Hipposideros ater is said to be beetles and low-flying insects such as gnats and mosquitoes (Bates \& Harrison, 1997; Phillips, 1980). From our study a total of 2028 prey items were identified (Table 1). Coleoptera was the largest group predated on and constituted $41.81 \%$. The other basic food was Lepidoptera which accounted for $21.64 \%$. Constant food consisted of Diptera (19.77\%) and Hymenoptera $(5.32 \%)$. Supplementary food was Araneae, Blattaria, Isoptera and Hemiptera. Chance food taken was Orthoptera, Mantodea and Neuroptera.

Except for Araneae (Spiders) which constituted 1.97\%, all others in the droppings of $H$. ater were insects. The bats ability to consume non-flying prey on bushes or on the ground was obvious from the presence of spiders, beetles and lepidopteran larvae in their faeces.

Two other species of hipposiderid bats exist in this region known as the Kaliveli watershed, and exist sympatrically. These are the Fulvous Leaf-nosed Bat H. fulvus and Schneider's Leafnosed Bat $H$. speoris. The interaction and ecological dynamics between these three species has been investigated (Jones et al., 1994). This report suggested that the three species feed at different levels on different insects - $H$. ater at ground level and feeding on small insects, $H$. fulvus in the canopy and feeding
Table 1. The prey of Hipposideros ater.

\begin{tabular}{lllc}
\hline Prey & $\#$ & $\%$ & Category \\
\hline Araneae (Spiders) & 40 & 1.97 & SF \\
Orthoptera (Grasshoppers, Crickets, etc.) & 11 & 0.54 & OF \\
Mantodea (Mantids) & 9 & 0.44 & OF \\
Blattaria (Cockroaches) & 72 & 3.55 & SF \\
Isoptera (Termites) & 42 & 2.07 & SF \\
Hemiptera (Bugs) & 40 & 1.97 & SF \\
Coleoptera (Bettles) & 848 & 41.81 & BF \\
Neuroptera (Lacewings \& Ant - lions) & 8 & 0.39 & OF \\
Diptera (Flies) & 401 & 19.77 & CF \\
Lepidoptera (Butterflies \& Moths) & 439 & 21.64 & BF \\
Hymenoptera (Ants, Bees \& Wasps) & 108 & 5.32 & CF \\
& $\mathbf{2 0 2 8}$ & &
\end{tabular}

* inclusive of 9 larvae

\# - Number consumed; BF - Basic Food (>20\%); CF - Constant Food (5-20\%); SF - Supplementary Food (1-5\%); OF - Chance Food (<1\%)

on insects of intermediate size, and, H. speoris close to the treeline and feeding on large insects.

Other authorities disagree and categorically state that all the three hunt close to ground (Bates \& Harrison, 1997; Brosset, 1962; Madhavan et al., 1978). It has specifically been mentioned that though they all hunt close to ground, the flying styles vary $-H$. ater is moderately fast and fluttering, $H$. fulvus is slow and fluttering, whereas $H$. speoris is slow, skilful and with continual changes of direction (Bates \& Harrison, 1997). Hence, it stands to reason that all three species can co-exist without competition, simply by feeding on insects flying at different speeds and in different styles.

Nevertheless the dynamics remain ambiguous. Only a detailed and comprehensive analysis of the prey spectrums of all three species (and, for that matter, all other microchiropteran bats) can resolve the issue. Comparative analysis is the need of the hour and is sure to repay further investigation.

\section{REFERENCE}

Bates, J.J. and D.L. Harrison (1997). Bats of the Indian Subcontinent. Harrison Zoological Museum, Kent, England, 258pp.

Borror, D. (1992). An Introduction to the Study of Insects. Harcourt Brace College Publishers, USA, 876pp.

Brosset, A. (1962). The bats of central and western India. Part II. Journal of the Bombay Natural History Society 59(2): 583-624

Jones, G., K. Sripathi and D.A. Waters (1994). Individual variation in the echolocation calls of three sympatric Indian hipposiderid bats, and an experimental attempt to jam bat echolocation. Folia Zoologica 43(4): 347-362.

Madhavan, A., D.R. Patil and A. Gopalakrishnan (1978). Breeding habits and some associated phenomena in some Indian bats. Part 4 - Hipposideros fulvus fulvus (Gray) Hipposideridae. Journal of the Bombay Natural History Society 75(1): 96-103.

Mani, M. (1990). General Entomology. Oxford \& IBH Publishing, New Delhi, 912pp.

Phillips, W.W.A. (1980). Manual of the Mammals of SriLanka. Part I, pp. 1116. Wildlife and Nature Protection Society of Sri Lanka.

Verzhutskii, B. \& M.E. Ramanujam (2002). On the prey of the Collared Scops Owl (Otus bakkamoena (Pennant)) at Auroville, Pondicherry. Zoos' Print Journal 17(11): 939-940.

\section{ACKNOWLEDGEMENT}

We sincerely thank the European Commission's Tropical Dry Evergreen Forest Project, Pitchandikulam Bio-resource Centre and Shakthi Herbarium for supplying the means and materials to carry out assessments of the faunal elements in the Kaliveli watershed region. 